\title{
Implant Registry to change in UK - Bar Codes Will Decrease Admin Costs
}

\author{
*PJW Verco \\ North Adelaide Medical Centre, Australia
}

Submission: February 20, 2014; Published: March 28, 2017

*Corresponding author: PJW Verco, North Adelaide Medical Centre, 183 Tynte Street, North Adelaide SA, 5006, Australia, Tel: +61 8 8267 4081; Fax: +61 88267 4976; Email: joeverco@verco.com.au

\section{News}

Breast implants and replacement hips will be printed with barcodes in a technological overhaul of equipment that could save the NHS $£ 1$ billion. The codes on various implants, medications and surgical tools will help medics track patients' care in a plan to reduce waste, save money and improve safety, the Department of Health (DOH) said. The technology is being introduced as a part of the Government's $£ 12$ million "Scan4Safety" project which aims to reduce the number of times patients are administered the wrong drugs and surgery is performed on the wrong part of the body. The scannable codes will show who administered treatment or performed surgery, and allow anything from a screw in a knee operation to a replacement hip to be tracked back if it becomes faulty. It will also help doctors to compare the effectiveness of different treatments. Jeremy Hunt, the Health Secretary, said it was a "world first" in health care. The scheme is being piloted in six NHS trusts in Derby, Leeds, Salisbury, Cornwall, North Tees and Plymouth. Early results show it could prevent deaths and save up to $£ 1$ billion for the NHS over seven years, the DOH said.

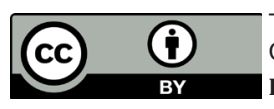

This work is licensed under Creative Commons Attribution 4.0 License DOI: $10.19080 /$ JFSCI.2017.02.555597

\section{Your next submission with Juniper Publishers will reach you the below assets}

- Quality Editorial service

- Swift Peer Review

- Reprints availability

- E-prints Service

- Manuscript Podcast for convenient understanding

- Global attainment for your research

- Manuscript accessibility in different formats

( Pdf, E-pub, Full Text, Audio)

- Unceasing customer service

Track the below URL for one-step submission https://juniperpublishers.com/online-submission.php 